\title{
Fenitization of ultramafic rocks around late carbonatites in the Kovdor Massif (Kola Alkaline Carbonatitic Province)
}

\author{
SKYLAR N MASSEY AND MAYA G KOPYLOVA
}

University of British Columbia

Presenting Author: smassey@eoas.ubc.ca

Intrusions of carbonatites are accompanied by extensive fenitization expressed in modal and cryptic metasomatism and recrystallization. We studied effects of fenitization around carbonate-rich veins ranging from carbonatites to carbonate phoscorites with varying modes of olivine and apatite. The carbonate-rich melts intruded older pargasite-bearing clinopyroxenites and olivinites of the polyphase 373-377 Ma Kovdor massif in the Kola Alkaline Carbonatitic Province. Carbonatites resorb olivines and clinopyroxenes leaving in these earlier silicates multiple carbonate and phlogopite inclusions. In contrast, carbonate-bearing phoscorites do not resorb silicates, but may show a separation into fine-grained olivine-rich selvages and carbonate-rich central parts of the veins. Both types of late veins, carbonatitic and phoscoritic give rise to ca. $20 \mathrm{~cm}$-wide zones of recrystallization and fenitization containing richterite and humite. The fenitization involved recrystallization of polycrystalline clinopyroxenites and olivinites (Fo89-91) that comprise the earlier magmatic phases of the Kovdor ultramafic rocks. Olivines and clinopyroxenes acquire a preferred optical orientation and elongation perpendicular to the veins and form megacrystalline clinopyroxenites, olivinites and phlogopite-rich rocks. The recrystallization of clinopyroxene is accompanied by Ti enrichment, $\mathrm{Al}, \mathrm{Na}$ and $\mathrm{Cr}$ depletion and replacement by fibrous richterite growing perpendicular to the contacts. In-situ trace element and $\mathrm{Pb}$ isotopic analyses will draw further constraints on the origin of megacrysts in the fenitization zones and shed light on the possible HIMU signatures of carbonatites. 